\title{
State Violence and Weaving: Implications of Aristophanes' Lysistrata for

\author{
Plato’s Statesman
}

\author{
Marina Marren
}

This paper uses Aristophanes' Lysistrata to draw out the central violent tension of the weaving paradigm in Plato's Statesman. In the Lysistrata, weaving is offered as a metaphor for a tyrannical refashioning of the polis. In strikingly similar terms, the Eleatic Stranger of the Statesman proposes weaving as a metaphor for the best form of government. What is laughed off in the play, the characters of Plato's dialogue seem to take seriously. Through a comparative reading, I argue that the interpretations of the Statesman that take weaving as a paradigm for the best government of state, not only miss the comedy in the Stranger's discussion of statesmanship, but also the tragic allusions to tyranny. Furthermore, by drawing out the dialogue's resonance with comedy, I conclude that the weaving paradigm succeeds in giving us a means for identifying tyranny in the Statesman; even when tyranny appears dressed up in a political science ostensibly formulated with the best of intentions.

\section{Introduction}

Weaving, politics, and violence cross paths already in Homer. Both Aristophanes and Plato inherit epic lore and with it an image of Penelope, who weaves by day and takes her work apart by night, because that is her wily trick to forestall the hotheaded suitors. Odysseys, the king of Ithaca, is away and Penelope must find some means of saving herself from being forced into a new marriage. If she fails, the power in the kingdom transfers hands. What resorts does an ancient Greek queen have when it comes to politics? Homer's answer is: weaving, which in the Odyssey is not merely a woman's work. Neither is weaving meant to mark a simple domestic chore in Aristophanes' comedy, where the main character's Lysistrata's - name picks up on the trope of undoing, unraveling, and dissolving, while her 
choice of an image for doing away with the menace of war is weaving. ${ }^{1}$ Later still, in Plato's pronouncedly political dialogue - the Statesman - weaving is the paradigm for the royal political art. Metaphorical use of weaving, which is the final paradigm for rule in Plato's Statesman, shows a special consonance with Aristophanes' presentation of weaving in the Lysistrata. The connection between the dialogue and the play emerges when we study prescriptions of violence, which weaving as the paradigm for rule issues in the Statesman (293a - e and 300d), in view of the comedic portrayal of weaving, which Aristophanes' Lysistrata proposes as a political solution to the Peloponnesian War $(574-86){ }^{2}$ A thorough discussion of Plato's use of paradigms as models in the Statesman is outside of the scope of the present analysis. Plato weaves the Statesman out of epos, drama, pre-Socratic thought, and out of sophistical arguments and distinctions. However, to discern patterns in Plato's web is not the same as to confine oneself to any one of them. It is difficult to see that weaving fails as a solution to the problems of politics, because it is formally akin to Plato's art. Thus, it is especially pressing that we explain why this particular model for rule cannot be meant prescriptively in the Statesman.

Aside from using the same language and imagery as Plato's dialogue to describe the management of a state, what does a vulgar comedy about violence and sex have to do with the dialogue's serious search for the best statesmanship? Recent scholarship on the central passages in the Statesman (e.g., on the diaretic searches for the best ruler, Miller 2017; and on the mythic time of Cronus, Barney 2011) pays close attention to comedy in Plato. Following this research, I go further to prove that unless we recognize Plato's direct allusion to the Lysistrata as it appears in the weaving passages, and through this understanding perceive the tragedy revealed thereby, we miss out on a number of serious philosophical

\footnotetext{
${ }^{1}$ I am indebted to Louis Arthur Ruprecht, Jr. for this insight into the parallels between Penelope's unweaving of Odysseys's funerary cloak and the images of unraveling or dissolution that Lysistrata's name evokes.

2 On the subject of comedy in general, and more specifically, on the relationship between Aristophanes' plays and Plato, see Freydberg (2008), Strauss (1966), Patterson (1982), and Hyland (1995), who warns against distilling from the dialogues some kind of "Plato's theory of comedy." Instead, Hyland urges us to "look ... closely at the dialogues themselves, at the way comedy arises within them and the way they portray the philosophic life as comic" Hyland, A. Drew. Finitude and Transcendence in the Platonic Dialogues (New York: State University of New York Press 1995), 131. See analyses of Plato's dialogues as works of drama in Zuckert (2012), Nails (2006), Blondell (2002), Freydberg (1997), Arieti (1991), Sallis (1975), Wolz (1963, 1970).
} 
conclusions that the Statesman offers. ${ }^{3}$ Comedy, then, far from being merely tangentially related to Plato's thinking, is precisely what avails us of several key insights into his political thought. One such insight recommends that we refrain from treating prescriptively such dialogical models as the master weaver of the Statesman or the philosopher king of the Republic. Both of these, and other dialogical images having to do with model rulers and supposedly best regimes, that we find in Plato are rather meant as diagnostic elements; as ideas that both reflect and elicit our deepest tendencies and predilections - be they idealistic, wishful, self-congratulatory, or coldly calculative in kind. ${ }^{4}$ Comic self-ridicule is a practice attendant upon our capacity to know ourselves. As I bring Aristophanes' comedy to bear on Plato's dialogue, I aim to make it conducive to an examination of philosophical ideas found in the Statesman as well as to our self-examination. Plato's Statesman is most widely considered to be a dialogue about the nature and the possibility of the best government for a given state. However, if we put our trust in weaving, as the best form of rule, and aim to apply it to our lives, then we miss the point of Plato's dialogical philosophizing, and end up installing tragically violent forms of government against which Plato's allusions warn.

\section{Review of Literature on Weaving as a Paradigm for Rule in the Statesman}

Lane (1998) addresses the relationship between violence and weaving in the Lysistrata. However, she suppresses the role of violence in her corresponding treatment of the Statesman, where she sees the dialogue as a "technical correction" to Aristophanes' play. The problem with her assessment of the Statesman is that it threatens to prescribe the tyranny that Aristophanes' play intends to have its audience dismiss with laughter. Vetter (2005) discusses both the Lysistrata and the Statesman and arrives at the conclusion that "Aristophanes serves as an important precursor to Platonic dialectic." ${ }^{5}$ However, Vetter does

\footnotetext{
${ }^{3}$ See also essays on the Statesman in a more recent volume. Bossi, Beatriz and Robinson, M. Thomas. Plato's Statesman Revisited (Berlin, De Gruyter 2018).

${ }^{4}$ Strauss (1996b) writes that the "action of the Republic can be said to consist in first arousing spiritedness or the virtue belonging to it, that is to say, zeal dedicated to non-understood justice, that is, what we now mean by political idealism, and then purging it." Strauss, Leo. "The Origins of Political Science and the Problem of Socrates." Interpretation (1996b) 23(2): 129 - 206, 192.

${ }^{5}$ Vetter, P. Lisa. Women's Work as Political Art: Weaving and Dialectical Politics in Homer, Aristophanes, and Plato (Oxford, UK: Lexington Books 2005), 66.
} 
not examine the relationship between the two works in terms of their reliance on weaving as a metaphor for politics. Miller (1980), although he recognizes that the weaving section signals the fact that "the dialogue is in crisis," 6 sees this crisis as a problem that has more to do with method than with the upsurge of violence, which the weaving metaphor implies. ${ }^{7}$ Sayre (2006) connects the Statesman to the Lysistrata on the basis of weaving and differentiates between the use of weaving in the two works. He claims that the comedy lays out the "steps" and the dialogue points out the "skills" needful to apply the model to the governance of the state. ${ }^{8}$ Strauss (1966) thinks that the Lysistrata "anticipating the Eleatic stranger in Plato's Statesman [shows] ... that the women's work in handling wool is a perfect model for bringing order into the disordered affairs of the city." ${ }^{9}$ It looks as if Strauss is comfortable with propagating Lysistrata's tyranny and seeing it applied to politics through the insights of Plato's Statesman. Benardete (2006) explains why it is the case that Strauss takes Lysistrata's “solution" as the Stranger's answer to political dilemmas when he writes, "[t]he woof is the herd, the warp is the ruler, and this interweaving of commandment and obedience is the web of political science as the art of caring for the whole city." ${ }^{10}$ In the alignment of ruler and herd with woof and warp, Benardete brings the myth about the rule of ${ }^{6}$ Miller, Mitchell. The Philosopher in Plato's Statesman (Boston, MA: Martinus Nijhoff Publishing
1980), 64.

${ }^{7}$ Miller's (2017) recent treatment of weaving in the dialogue confirms the fact that he does not take weaving to have anything to do with violence. See Miller, Mitchell. "Nôesis and Logos in the Eleatic Trilogy, with a Focus on the Visitor's Jokes at Statesman 266a-d." The Plato's Statesman: Dialectic, Myth, and Politics. Sallis, J. ed. (New York, NY: SUNY Press Publishing 2017), 107 - 36, 127 - 28. The other authors, who comment on weaving and who are published in the same volume (Günter Figal, Eric Sanday, and James Risser) overlook the cruel measures, which weaving as the paradigm for rule prescribes. Figal thinks that "weaving proves to be well suited to the task of determining the statesman craft." "On Dialectics in Plato's Statesman," $137-48,143$. Sanday sets out to prove the "success of the paradigm of weaving." "Paradigm and Dialectical Inquiry in Plato's Statesman," 149 $-70,155$. Risser sees weaving as a model that the interlocutors use in order to practice their skill of making and setting up examples. "The Art of the Example in Plato's Statesman," 172 - 82, 176.

${ }^{8}$ Sayre, M. Kenneth. Metaphysics and Method in Plato's Statesman (Cambridge, UK: Cambridge University Press 2006), 96. Similarly Smith (2018) in his article entitled "The Groundwork for Dialectic in Statesman 277a-287b," sees weaving, in conjunction with care and due measure, as the proper paradigm for the dialectical inquiry." Smith, C. Collin. "The Groundwork for Dialectic in Statesman 277a-287b," The International Journal of the Platonic Tradition (2018) 12(2): 132 - 50.

${ }^{9}$ Strauss, Leo. Socrates and Aristophanes (New York, NY: Basic Books Publishing 1966a), 202.

${ }^{10}$ Benardete, Seth. The Being of the Beautiful (Chicago, IL: University of Chicago Press 2006), III.113. 
Cronus and Zeus $(268 \mathrm{~d}-274 \mathrm{e})$, as well as the pre-mythical rendition of the ruler as the herdsman, to bear on the discussion of weaving. Likewise, Miller wonders about the similitude between the divisions that articulate the art of weaving and the "divisions in the 'earlier discourse' [which have] proven unsatisfactory and insufficient." ${ }^{11}$ However, having expressed their questions and observations, Lane, Sayre, and Strauss proceed to treat the discussion of weaving as a cogent model for politics. Whereas, Miller takes it to be a necessary step in the young Socrates' education. ${ }^{12}$ None of the authors offer an analysis that would compare the lines about weaving in the dialogue with those in Aristophanes' play in order to ask the question: What does laughter reveal to us about violence - the violence that the play acknowledges is unavoidable if Lysistrata's weaving and its dialogical counterpart are taken up as a serious paradigm for political life? Authors (e.g., Rosen 1995, Rowe 1996, De Chiara-Quenzer 1998, Pender 2003, Browning Cole 1991, Moore 2016), who examine the meaning of paradigm $(\pi \alpha \rho \alpha ́ \delta \varepsilon 1 \gamma \mu \alpha)$ in the Statesman, and who argue for the important role that models play in education, politics, and ethical life do not discuss the possible epic, dramatic, or literary examples on which Plato, himself, might have relied to construct the weaving paradigm in the Statesman. I seek to correct this oversight and analyze weaving in the Lysistrata as the model after which the paradigm for rule takes in Plato's dialogue.

\section{Politics in the Lysistrata}

The shadow of the disastrous Sicilian expedition (413 BC) falls over the first

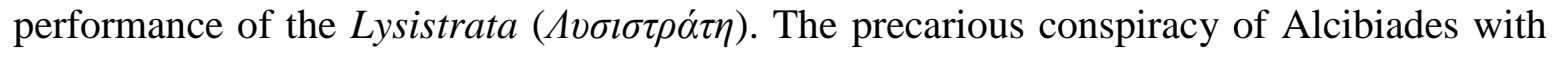
the Spartans and his negotiations with the Persian satrapy help instigate the Athenian oligarchs to stage a revolt against the democracy. The oligarchs take power in $411 \mathrm{BC}$. The reign of the four hundred, and then of the five thousand oligarchs, is brief but it marks the year in which the Lysistrata - a play about the inanity of war - is produced. In his introduction to a study of logos and eros in Aristophanic comedy, Freydberg (2008) interprets the Greeks'

\footnotetext{
${ }^{11}$ The Philosopher in Plato's Statesman, 60.

12 The young Socrates speaks at length in the Statesman. However, the dialogue opens with the replicas from old Socrates, who we know as the narrator of the Republic, Lysis, Charmides, Euthydemus, and Protagoras.
} 
warmongering foolishness in the Lysistrata as "the result of male irrationality." 13 We can fine-tune Freydberg's initial suggestion and state that the self-serving shortsightedness of particular representatives of the city's male leaders serves as the laughing stock for the play. The Lysistrata conceived in the tumult of the times, albeit playful, relies on the audience's acute awareness of a hardly laughable matter - the pain of war. Vickers (1997) cites a slew of scholars who dismiss or undermine the political nature of Aristophanes' work. He attributes this phenomenon to the commentators' penchant to avoid ambiguity and decry the presence of "hidden meanings" in the interpretation of classical works. In the Lysistrata, the political meanings are not hidden. They not only surround the play from without; they are right at the surface as well. The Lysistrata is explicitly about war, sex, and the city or, to put it in less jarringly contemporary terms, it is about polemos, eros, and polis. ${ }^{14}$

Strauss (1966), in the first line of his analysis of the Lysistrata, draws our attention to the fact that " $[\mathrm{t}]$ his is the only play [by Aristophanes] whose title designates a human individual. It is the only play whose title designates the chief character or the human being responsible for the design that is executed in the play." ${ }^{15}$ Aside from wedding the plot to the main character's choices and uniqueness (Lysistrata, after all, is the woman who seeks to do away with the war), the name used as the title also suggests that the play's content is about "releasement, liberation, [and] loosening." "The name "Lysistrata" evokes as well the sense of to "dissolve" or to "break up into parts." The meaning of the root term ( $\lambda v ́ \varepsilon v)$ is at least bi-valent. The name recalls both a resolution or a liberation and a dissolution or a disintegration. ${ }^{17}$ In this double register, the war puts strain onto men, and the men pass it on

${ }^{13}$ Freydberg, Bernard. Philosophy and Comedy: Aristophanes, Logos, and Eros (Bloomington, IN: Indiana University Press 2008), 6. See, further, Freydberg's chapter on the Lysistrata, 162 - 95.

${ }^{14}$ Vickers, Michael. Pericles on Stage (Austin, TX: University of Texas Press 1997), ix - xx. Vickers further reports that Alcibiades resorts to even harsher measures to punish Eupolis' comedic attacks against his persona (xviii). Vickers cites Alcibiades' 415 BC decree against direct lampooning as the reason for Aristophanes' omission of Alcibiades' name in his Birds, for instance.

${ }^{15}$ Socrates and Aristophanes, 195.

${ }^{16}$ Freydberg, Philosophy and Comedy, 194.

${ }^{17}$ In some sense, desis is summarily outlined at the outset of the play. The thickening of the action in the Lysistrata amounts to the play's setting; i.e., the war and the resultant sex strike. The whole of the Lysistrata, therefore, can be seen as a lusis - as a protracted search for a release of built up tension. For the customary meaning of the terms desis and lusis see Aristotle. On Poetics, Benardete, S. and 
to women. To combat this, Lysistrata rallies with Athenian, Boeotian, and Spartan women to deny sex to their husbands. Her successful ploy destabilizes also the initial stress-relation. Lysistrata's plan reveals that it is not the war that is the cause of all trouble, but that men having engaged in war pain both themselves and their wives. Whereas in reality, the outcome of the Peloponnesian war will be anything but pleasant and lighthearted, in the play, Lysistrata's tactic of abstinence prevails and eventually leads to the celebration of life and love. However, we note that Lysistrata and her female comrades are ready if need be to set not only sex, but also peace aside $(574-79)$. On this view, the women are no less apt at violence than men. Whether the women desire power or, as Olson (2012) thinks, "dialogue"18 and change, is not at issue here. The main point is that when pressured the women are capable and willing to go as far as men in their choice of violent means to secure the desired end, which is paradoxically peace.

Markedly, Lysistrata offers two kinds of measures that can be taken against the inanity of war. ${ }^{19}$ Lysistrata's sex solution is one. Another one is her violent or, more pointedly, her tyrannical answer to the proliferation of the warmongering moods of men. Lysistrata's second solution is presented as the metaphor of weaving $(567-86)$. The play laughs it off, but Plato's dialogue makes weaving into a paradigm for politics. Plato's

Davis, M. trans. (South Bend, IN: St. Augustine's Press 2002), chapters 15, 25, and pages xxvii xxviii.

${ }^{18}$ Olson, S. Douglas. "Lysistrata's Conspiracy and the Politics of 412 BC," No Laughing Matter: Studies in Athenian Comedy. Marshall, W. C. and Kovacs, G. eds. (London, UK:

Bristol Classical Press 2012), 69 - 81. See, also, Vickers's Aristophanes and Alcibiades: Echoes of Contemporary History in Athenian Comedy (Boston, MA: Walter de Gruyter Publishing 2015), 119 - 20, where Vickers argues against Whitman and with Mastromarco, who understands Lysistrata's character as taking on a masculine, if not also a power-seeking role.

${ }^{19}$ In the Statesman, the Stranger's and the young Socrates' discussion of bigness $(284 \mathrm{e}-286 \mathrm{~b})$ and length $(286 \mathrm{~b}-286 \mathrm{e})$, which supersedes the Stranger's divvying up of the "art of measurement" (284e), ends up preferring the "fitting" as the measurement appropriate to "make our blame and praise

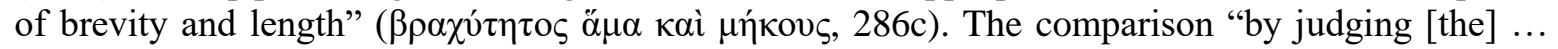
lengths relative to one another" (286c) is set aside and so is "any fitting length relative to pleasure"

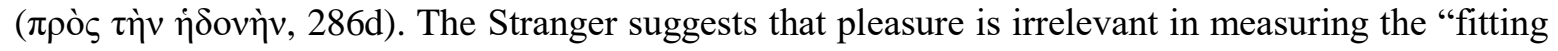

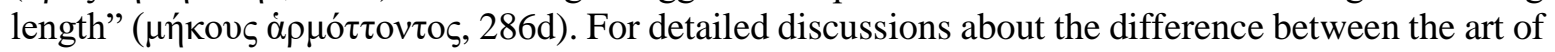
measurement and essential measure, consult Miller (1980, 71 - 2), Sayre (2006, 145 - 89), and Krell, David. "Talk to the Animals: On the Myth of Cronus in the Statesman." Plato's Animals: Gadflies, Horses, Swans, and Other Philosophical Beasts. Naas, M. ed. (Bloomington, IN: Indiana University Press 2015), 35 . 
Statesman ends up preferring exactly that, which the Lysistrata dismisses. As the dialogue settles on weaving, it welcomes the kind of brutality in politics, which the erotic denouement of Aristophanes' comedy avoids. The main characters' take on weaving suppresses the fact that is apparent in Lysistrata's example. In the Lysistrata, weaving has to do with putting together human coalitions and dissolving human lives. Lysistrata is using weaving as a metaphor for quieting the disarray of war and restoring order. The image of worked over woven wool portrays her view of a well-ordered polis. Lysistrata asks us to

[i]magine the polis as a fleece just shorn. First put it in a bath and wash out all the sheep dung; spread

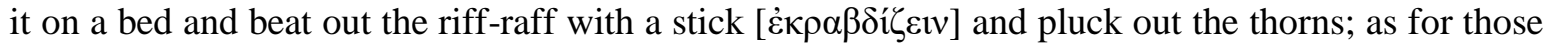
who clump and knot themselves to snag government positions, card them out and pluck off their

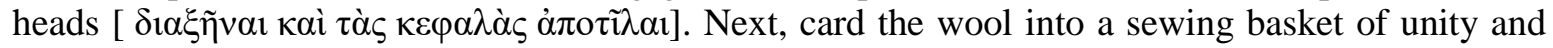

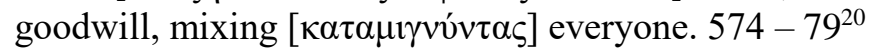

Lysistrata's metaphor prescribes executions, torture, and exile as well as the forced mixing of the "cleansed" peoples. Her political prescriptions are hardly democratic and they are certainly violent. Aristophanes has history as an example for his play. Consider for example the Athenian expulsion of the Hestiaeans and the consequent establishment of an Athenian colony on Oreus $(446$ - 445BC) or Pericles' punitive mission to Samos (440 439BC), where the oligarchs' attempt to snuff out democracy was expediently, violently, in short - undemocratically - put down.

\section{The Role of Aristophanes' Play in the Statesman}

Let us consider next the textual resonances between weaving as a metaphor for rule in the Lysistrata and in the Statesman. Socrates agrees when the Stranger offers that

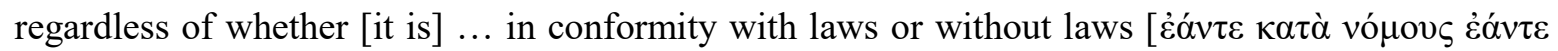

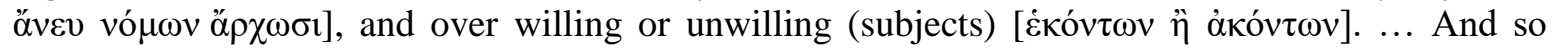
regardless of whether they purge the city for the good by killing [aं exiling [ $\dot{\kappa} \kappa \beta \alpha \dot{\alpha} \lambda \lambda \sigma \nu \tau \varepsilon \zeta]$, or they make the city smaller by sending out colonies somewhere like swarms of bees, or they increase it by importing some different people from somewhere or other outside and making them citizens, as long as they are employing science and the just and, in keeping safe, make

\footnotetext{
${ }^{20}$ Aristophanes. Birds; Lysistrata; Women at the Thesmophoria. (Loeb Classical Library No.
} 179). Aristophanis Comoediae. Henderson, J. trans. (Oxford, UK: Oxford Classical Texts 2000), 349. 
it better from worse to the best of their ability, we must state that this then is the only right regime. $293 c-e^{21}$

The Stranger's meaning is unambiguous. Only the rulers have the "know-how" ( $\tau$ ov̀ $\varsigma \alpha \propto \rho \chi \nu \tau \alpha \varsigma \dot{\alpha} \lambda \eta \theta \tilde{\omega} \varsigma \dot{\varepsilon} \pi 1 \sigma \tau \eta \dot{\mu} \mu v \alpha \varsigma, 293 \mathrm{c}$ ) or the true knowledge of the art by which the state is supposed to be run. The use of extreme violence (killing and exiling) against the population is justified even if it is not permitted in the written laws and even if the citizens disagree with the decrees and actions of the rulers. Notice the close similarity between these lines from the dialogue and the violence prescribed by the weaving scene in the Lysistrata (565 - 86), where she says:

Well, first as we wash dirty wool so as to cleanse it, so with a pitiless zeal we will scrub. Through the whole city for all greasy fellows; burrs too, the parasites, off we will rub. That verminous plague of those degenerate refugees soon between thumb ... we'll crack. All who inside Athens' walls have their dwelling into one great common basket we'll pack. Disenfranchised or citizens, allies or aliens, pell-mell the lot of them in we will squeeze. ... As for disjointed and far colonies, Them you must never from this time imagine as scattered about just like loose strands of wool. Each portion we'll take and wind in to this centre, inward to Athens loyal and true, Till from the vast heap where all is

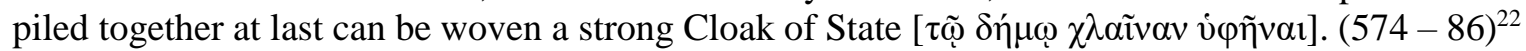

Both the Stranger and Lysistrata advocate for the harsh treatment of the citizens. In both cases there is a method that the ones who rule employ. The passage in which Lysistrata suggests that women know how to run the city because they know the art of weaving mentions the separation of "grease and filth" from the fabric. This is her metaphor for driving out "bad citizens" $(574-76){ }^{23}$ Stretching, scourging, carding "matted coalitions," 24 and plucking off "head clumps" 25 is used as an analogy of separating out and preparing the shorn wool for being worked over into suitable material. The mixing of the desirable parts that follows is cast less metaphorically. Lysistrata says,

\footnotetext{
${ }^{21}$ Benardete, The Being of the Beautiful, III.46.

${ }^{22}$ Aristophanes. Lysistrata. Lindsay, J. trans. (London, UK: Fanfrolico Press 1926).

${ }^{23}$ Here, I am using an anonymous translation of the Lysistrata. Crofts, T. ed. (New York, NY: Dover Publishing 1994).

${ }^{24}$ This is how Benardete translates lines 574 - 77 from the Lysistrata in The Being of the Beautiful, III.153, nt. 29.

${ }^{25}$ Ibid.
} 
Gather into a basket the shared good will of all, mixing together the metics, any friendly stranger, and anyone who solely owes money to the treasury. ... [T] he cities, those which are your colonies, adjudicate with discernment, because they now lie apart like flock. And then from all of them ... weave a cloak for the people. $580-86^{26}$

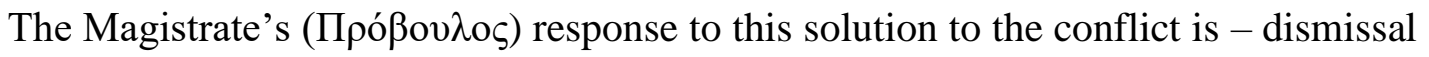
$(587-88)$. Yet, instead of objecting to its violence (we are, after all, talking about murder, torture, coercion, forced mingling and separation of peoples, and redistribution of property), the old man dismisses it on the grounds that it is ... weaving! He is put off by the suggestion that the management of the polis is akin to a woman's work. The aged Magistrate exclaims: "Is it not shameful that they treat all" of the affairs of the city by "thrashing and by winding?"

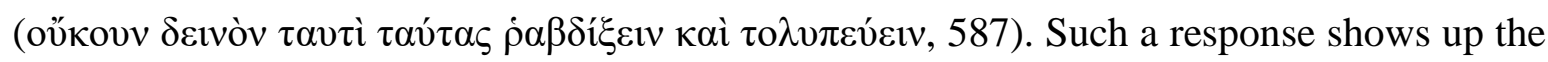
Magistrate's incompetence. The old man's response is funny. However, it is not funny that Lysistrata intends, if necessary, to end the war not by a peaceful sex strike, but in accordance with this much crueler plan.

Lysistrata gives a name to the paradigm for the forced disenfranchisement, resettlement, purging, and mixing of the peoples. She calls it "weaving" (v́qú $\omega, 586)$. The Stranger, in the Statesman, adopts the same root term for the skilled ruler and calls him a

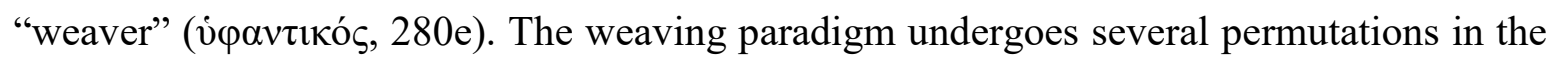
Statesman, moving away from the matters that are directly related to the craft of weaving and toward the matters that are related to the politics of state. However, the continuity between weaving as a craft and statesmanship (which is based on the model of weaving) is preserved until the end. The passages that relate to weaving most immediately are at $279 \mathrm{a}-\mathrm{e}$. The Stranger establishes a direct analogy between cloak making, which is the product of weaving, and statesmanship at 280a. The Stranger recommends that statesmanship : state :: clothesmaking : clothes and, furthermore, that "weaving differs in no other way, but in its name

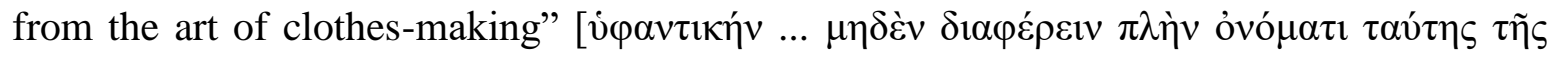

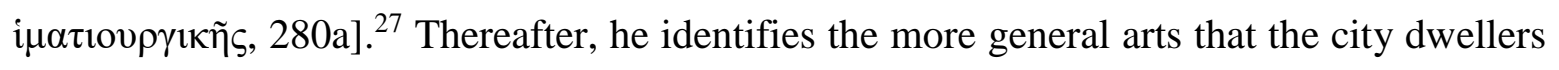
practice and compares these to the specific arts, which go into weaving $(280 \mathrm{a}-\mathrm{e})$. At $288 \mathrm{a}$ - e, the list of arts that are specific to the needs of the city is enlarged. There, the Stranger

\footnotetext{
${ }^{26}$ Ibid.

${ }^{27}$ Translation by the author.
} 
recommends again that in separating the art of the statesman from the other arts we should follow the analogy with weaving $(279 a-290 a)$. That analogy identifies "the arts that were supplying tools for weaving as co-causes" (287c). This, further, allows us to examine the productive arts that keep the city running with an eye on understanding how to differentiate between the craftsmen who have the know-how of their art and the charlatans $(299 \mathrm{a}-\mathrm{e})$. The ruler who directs and oversees the work of the auxiliary craftsmen is the perfect statesman $(280 \mathrm{e}, 311 \mathrm{a}-\mathrm{c})$. Although, the ruler himself might not engage in the preparatory and auxiliary crafts, he organizes the city based on the same principle as the weaver uses when he runs together the woof and the warp $(281 \mathrm{a}, 282 \mathrm{~d}-283 \mathrm{~b}, 305 \mathrm{e}-311 \mathrm{c}){ }^{28}$ The Stranger tells us that the ruler's art - if it is properly political - ought to be able to weave everything together in the city perfectly or correctly ( $\sigma v v v \varphi \alpha i ́ v o v \sigma \alpha v$ ỏ $\rho$ ó $\tau \alpha \tau \alpha, 305 \mathrm{e}$ ). Whatever else the statesman may turn out to be on this paradigm, he is the master weaver and therefore the violence of the auxiliary arts accrues to him. However, we see this violence clearly only if we look closely at Lysistrata's description of the sorts of things that go into making the material out of which to weave the cloak of state (disenfranchisement, forced resettlement, exiles, killings, forced mixings, etc.). The master weaver weaves the state together on the basis of violence required to produce the clean yarn and the suitable fabric.

Both Aristophanes' Lysistrata, who describes how the yarn must be prepared in order to finally weave the "Cloak of State" and Plato's Stranger, who goes over the sorts of activities that are needful for the paradigm of the statesman-weaver, tread close to ancient history. Burckhardt (1998) refers us to synoecism - a process by which a "locality usually already settled, but not previously fully fortified" was established. It was a necessary, but as Burckhardt explains, an oftentimes painful political solution, which aimed to match the growing power of neighboring communities. Burckhardt traces the polis with its governmental structure of "prytaneis (councillors) and ... archontes (chief administrators) and ... council bouleuterion" back to synoecism and posits that without this practice, "the full development of Greek culture would not have been conceivable." 29 He draws on "the clearly recorded examples of the historical period [from which] ... we learn of the sacrifices

\footnotetext{
${ }^{28}$ See Benardete, The Being of the Beautiful, III.113.

${ }^{29}$ Burckhardt, Jacob. The Greeks and Greek Civilization (New York, NY: St. Martin's Press 1998), 45.
} 
this synoechism might cost: violent resettlements of resisting populations or their extermination. What can only be guessed at is the misery of the many who complied." 30 In Aristophanes' play, Lysistrata hearkens back to a synoecism of sorts in order to, simultaneously, punish the wrongdoers and bring order to the polis. However in the dialogue, the weaving of the statesman, which necessarily includes the auxiliary (and as I argue on the example of the Lysistrata) violent arts, need not be a response to the troubled times, but rather a prophylactic, i.e., a preemptive organizing measure. Burckhardt goes on to say about synoecism that "[t]hese measures must usually have been carried out by powerful tyrannical minorities." 31 This historical fact does not exonerate the measures of strengthening the polis and of ruling it, as weavers do, which the Stranger proposes in the Statesman. Instead, set against the backdrop of synoecism, the Eleatic Stranger's weaving paradigm looks all the more menacing. It suggests that the Stranger has tyranny in mind.

What are we to make of the license that the Stranger attributes to the master weavers at $300 \mathrm{~d}$ ? He says: "the statesman will ... do many things by his art, as far as his own action goes, without any regard for the writings, whenever he is of the opinion that, contrary to what has been written by him ... different things are better" (300d). We may be talking here about prudent choices, which are not prescribed or anticipated by the written law, but for which a given situation calls. Indeed, further conversation circles around to the matter of the truth and knowledge of political science $(300 \mathrm{~d}-301 \mathrm{~d})$. However, if we consider that the many cannot rule well and that, therefore, there must only be a few or even but a single ruler; and if, moreover, we remember that the sorts of things that the rulers do (based on their knowledge of truth and craft) include acts of violence (unconstrained by law) against the ruled (293d e), then we are faced with the conclusion that weaving is prescribed as beneficial, but that it is implicitly harmful.

Whereas the characters of the comedy scoff at the violent solution to the violence of war, in the dialogue the Stranger goes on to adopt and prescribe artful violence. The presentation of weaving as a craft works over the elements, which make up the polis. The divisionary and combinatory remixing is called the "royal art" (280a). The Stranger tells us

\footnotetext{
${ }^{30}$ Ibid.

${ }^{31}$ Ibid.
} 
that it "does not at all differ except in name from ... cloakmaking" (280a), which is the "political art" (280a). The master-craft - the royal art - is weaving. Cloakmaking is politics. ${ }^{32}$

As Strauss observes about the Lysistrata, "[t]he women do not deny that they intend to set up tyranny." 33 However, once the men agree to peace the threat of tyranny is abated. This is not the case in the Statesman. On the contrary, because the best king rules by art and often without regard for the written laws, ancestral customs, and those things that are perceived as being good by the many $(297 \mathrm{a}-\mathrm{d})$, the line between the best kingship and tyranny is easily erased. All that it takes for the tyrant to rise to power is that he pretend to be as knowledgeable about rule as the best king is supposed to be $(301 \mathrm{c}-\mathrm{d})$. In fact, just as the best king is said to do also the tyrant "acts neither in conformity with laws nor in conformity with usages, and ... he pretends, just as if he were the knower [that] ... the best has to be done contrary to what has been written" (301c) down. The Lysistrata is funny because it does not claim to have secured a safe distance and a means of distinguishing between tyrannical acts and intentions and those of well-meaning individuals. The comedian exposes the shaky and duplicitous foundations of the supposed righteousness of violent acts. The woman who wants to end the war is accused of hubris and rightly so. She proposes killings as a means of untangling the warp of animosity. In effect, Lysistrata's weaving solution aims to redirect the aggression of war and aim it at the incompetent and corrupt natives of the city. Yet, her threats remain empty, all ends well, and we laugh. By contrast, the truth of Plato's and Aristophanes' own political situation is that the Athenians are both all too serious in their pursuit of militaristic expansion and that they fail to rise up against the violent executions of their own citizens (e.g., the aftermath of the battle of Arginusae). Unmoved by the self-reflection that Aristophanic laughter intends to bring about, the city

\footnotetext{
32 If we follow the Stranger's alignment of warp and woof (282e - 283a) and Benardete's (2006) reflection on the metaphorical implications that ensue (The Being of the Beautiful, III.113), we notice that the relationship between the people and the ruler (the woof and the warp) has been modified since the introduction of the herdsman metaphor and the development thereof in the Stranger's myth (268e $-275 a)$. The ruler is no longer separated from the herd as a divine overseer. The invocation of Athena and Hephaestus and the reiteration of Prometheus' myth $(274 \mathrm{c}-\mathrm{d})$ prepare the ground for taking up art as the paradigm for the science of statesmanship. Since Athena is subservient to the blacksmithgod (274c), wisdom is made to serve craftsmanship. Miller is right to observe that Plato is giving us the paradigm of "weaving [that] mirrors the dialogue as a whole" (The Philosopher in Plato's Statesman, 60).

${ }^{33}$ Socrates and Aristophanes, 204.
} 
fails to change its course. Athens loses the war and this tragic loss ushers in suffering and pain.

\section{Conclusion}

We see that weaving as the paradigm for rule in the Statesman is problematic if we trace this model back to its comedic roots. The comedy that throws a wrench into the systematic argumentation and into those forms of order, which are derived from it gives us a sense of the disorderly. Instead of seeing this disorder as threatening anarchy and mysology, or even as an intimation of the meaninglessness of life, we could see the lesson of comedy as I articulated it in my analysis of the dialogue.

Laughter avails us of a distance from ourselves and, thereby, allows us to move closer to serious self-understanding without which we cannot give due care to our political life. How can one engage in politics and public life thoughtfully, if one does not expend much thought in an attempt to know oneself? In the Philebus, Socrates speaks about the "nature of

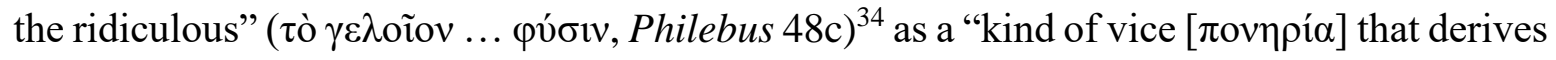
its name from a special disposition; it is, among all the vices, the one with a character that stands in direct opposition to the one recommended by the famous inscription in Delphi" (48c). The inscription at the entrance to the temple of Delphic Apollo commands: "Know Thyself." Socrates' joke, here, hinges on the fact that the ridiculous stands in direct opposition to our self-knowledge. Comedy makes use of our personal downfalls and faults to which we are either purposefully or unknowingly blind. Our quirks, our strong convictions and predilections are funny precisely when we take them seriously; more seriously than we should. Yet, the vice to which Socrates points, is vice strictly only if we remain in the condition of denying ourselves the possibility to laugh at ourselves, to see through the blinding effects of both our good intentions, and our problematic habits. Comedy and the Delphic injunction, work in tandem. The latter is a life-long exercise that is then serious, when it is ongoing, and when it seeks, but does not claim completion. The former - comedy that is - is only then vicious when it makes light of our downfalls while arousing no impetus

\footnotetext{
${ }^{34}$ Plato. Philebus. Frede, D. trans. The Complete Works of Plato. Ostwald, M. ed. (Indianapolis, IN: Hackett Publishing 1997).
} 
to reflect on the implications of our limited and finite nature. Of course, in that guise, it is no longer comedy, but rather something gratuitously grotesque and even tragic. If good comedy, or put better, if comedy that is well received, reveals to us both the vulnerable and the dangerous aspects of being human and thereby welcomes us to a serious study of ourselves, then it is a fine and a good thing if every now and again the joke is at our expense.

Marina Marren

University of Nevada, Reno

\section{Bibliography}

Arieti, A. James. 1991. Interpreting Plato: The Dialogues as Drama (Baltimore, MD: Rowman and Littlefield Publishing).

Aristophanes. 1926. Lysistrata. Lindsay, J. trans. (London, UK: Fanfrolico Press).

Aristophanes. 1994. Lysistrata. Crofts, T. ed. (New York, NY: Dover Publishing).

Aristophanes. 2000. Birds; Lysistrata; Women at the Thesmophoria. (Loeb Classical Library No. 179). Aristophanis Comoediae. Henderson, J. trans. (Oxford, UK: Oxford Classical Texts).

Aristotle. 2002. On Poetics, Benardete, S. and Davis, M. trans. (South Bend, IN: St. Augustine's Press).

Barney, Rachel. 2001. "Platonism, Moral Nostalgia, and the 'City of Pigs'." Proceedings of the Boston Area Colloquium in Ancient Philosophy 27(1): 207 - 27.

Blondell, Ruby. 2002. The Play of Characters in Plato's Dialogues (Cambridge, UK: Cambridge University Press).

Bossi, Beatriz and Robinson, M. Thomas. 2018. Plato's Statesman Revisited (Berlin, De Gruyter).

Browning Cole, Eve. "Weaving and Practical Politics in Plato's Statesman," The Southern Journal of Philosophy 29(2): $195-208$.

Burckhardt, Jacob. 1998. The Greeks and Greek Civilization (New York, NY: St. Martin's Press).

De Chiara-Quenzer, Deborah. 1998. "The Purpose of Philosophical Method in Plato's Statesman," Apeiron 31(2): 91 - 126.

Figal, Günter. 2017. “On Dialectics in Plato's Statesman.” The Plato's Statesman: Dialectic, Myth, and Politics. Sallis, J. ed. (New York, NY: SUNY Press Publishing), 137 - 148. 
Freydberg, Bernard. 1997. The Play of the Platonic Dialogues (Literature and the Sciences of Man) (New York, NY: Peter Lang Publishing).

Freydberg, Bernard. 2008. Philosophy and Comedy: Aristophanes, Logos, and Eros (Bloomington, IN: Indiana University Press).

Hyland, A. Drew. 1995. Finitude and Transcendence in the Platonic Dialogues (New York: State University of New York Press).

Krell, David. 2015. "Talk to the Animals: On the Myth of Cronus in the Statesman." Plato's Animals: Gadflies, Horses, Swans, and Other Philosophical Beasts. Naas, M. ed. (Bloomington, IN: Indiana University Press).

Lane, S. Melissa. 1998. Method and Politics in Plato's Statesman (Cambridge, UK: Cambridge University Press).

Miller, Mitchell. 1980. The Philosopher in Plato's Statesman (Boston, MA: Martinus Nijhoff Publishing).

Miller, Mitchell. 2017. "Nôesis and Logos in the Eleatic Trilogy, with a Focus on the Visitor's Jokes at Statesman 266a-d.” The Plato's Statesman: Dialectic, Myth, and Politics. Sallis, J. ed. (New York, NY: SUNY Press Publishing), $107-36$.

Moore, G. Holly. 2016. “The Psychagogic Work of Examples in Plato's Statesman," Philosophy and Rhetoric 49(3): 300 - 22.

Nails, Debra. 2006. “Tragedy Off-Stage.” Plato's Symposium: Issues in Interpretation and Reception. Lesher, H. J., Nails, D. and Sheffield, C. C. F. eds. (Cambridge, MA: Harvard University Press).

Olson, S. Douglas. 2012. "Lysistrata's Conspiracy and the Politics of 412 BC," No Laughing Matter: Studies in Athenian Comedy. Marshall, W. C. and Kovacs, G. eds. (London, UK: Bristol Classical Press), $69-81$.

Patterson, Richard. 1982. "The Platonic Art of Comedy and Tragedy," Philosophy and Literature 6(1): $76-93$.

Pender, E. Elizabeth. 2003. "Plato on Metaphors and Models," Metaphor, Allegory, and the Classical Tradition: Ancient Thought and Modern Revisions. Boys-Stones, R. G. ed. (Oxford, UK: Oxford University Press), 55 - 81.

Plato. 1962. Plato with an English Translation: The Statesman; Philebus; Ion (Loeb Classical Library) Lamb, M. R. W. trans. (Cambridge, MA: Harvard University Press).

Plato. 1997. Philebus. Frede, D. trans. The Complete Works of Plato. Ostwald, M. ed. (Indianapolis, IN: Hackett Publishing).

Plato. 1997. Statesman. Skemp, B. J. trans. The Complete Works of Plato Ostwald, M. ed. (Indianapolis, IN: Hackett Publishing).

Plato. 2006. Statesman. Benardete, Seth. trans. The Being of the Beautiful (Chicago, IL: University of Chicago Press).

Risser, James. 2017. "The Art of the Example in Plato's Statesman," The Plato's Statesman: Dialectic, Myth, and Politics. Sallis, J. ed. (New York, NY: SUNY Press Publishing), 171 - 182.

Rosen, Stanley. 1995. Plato's Statesman: The Web of Politics (New Heaven, CT: Yale University Press).

Rowe, Cristopher. 1996. "The Politicus: Structure and Form," Form and Argument in Late Plato. McCabe M. M. et al eds. (Oxford, UK: Clarendon Press), 153 - 78. 
Sallis, John. 1975. Being and Logos: Reading the Platonic Dialogues. (Duquesne, PA: Pennsylvania University Press).

Sanday, Eric. 2017. "Paradigm and Dialectical Inquiry in Plato's Statesman," The Plato's Statesman: Dialectic, Myth, and Politics. Sallis, J. ed. (New York, NY: SUNY Press Publishing), 149 - 170.

Sayre, M. Kenneth. 2006. Metaphysics and Method in Plato's Statesman (Cambridge, UK: Cambridge University Press).

Smith, C. Collin. 2018. "The Groundwork for Dialectic in Statesman 277a-287b," The International Journal of the Platonic Tradition 12(2): 132 - 150.

Strauss, Leo. 1966a. Socrates and Aristophanes (New York, NY: Basic Books Publishing).

Strauss, Leo. 1996b. "The Origins of Political Science and the Problem of Socrates." Interpretation 23(2): $129-206$.

Vetter, P. Lisa. 2005. Women's Work as Political Art: Weaving and Dialectical Politics in Homer, Aristophanes, and Plato (Oxford, UK: Lexington Books).

Vickers, Michael. 1997. Pericles on Stage (Austin, TX: University of Texas Press).

Vickers, Michael. 2015. Aristophanes and Alcibiades: Echoes of Contemporary History in Athenian Comedy (Boston, MA: Walter de Gruyter Publishing).

Wolz, G. Henry. 1963. Philosophy as Drama: An Approach to Plato's Dialogues. International Philosophical Quarterly 3 (2): 236 - 70.

Wolz, G. Henry. 1970. Philosophy as Drama: An Approach to Plato's Symposium. Philosophy and Phenomenological Research 30 (3): 323 - 53.

Zuckert, H. Catherine. 2012. Plato's Philosophers: The Coherence of the Dialogues (Chicago, IL: University of Chicago Press). 